\title{
PREPAREDNESS FOR EMANCIPATION OF YOUTH LEAVING ALTERNATIVE CARE IN SERBIA
}

\section{Anita Burgund Isakov and Jasna Hrnčić}

\begin{abstract}
The process of preparing young people for leaving alternative care is not sufficiently researched in Serbia. In order to define what support is necessary for their successful emancipation, this study of 150 young people in care aims to analyse both their preparedness for leaving alternative care, and whether the type of placement (kinship, foster, or residential) makes a difference to the level of preparedness. A mixed method approach was applied. Quantitatively, questionnaires assessing factors contributing to successful emancipation were administered. Qualitatively, transcripts of discussions from 5 focus groups, consisting of a total of 26 participants from all 3 types of placement, were analysed. Most of the youth in the sample indicated they have self-care and housekeeping skills, social skills to make friendships and connections, good grades in school, and aspirations for further schooling and starting a family. However, negative feelings such as disturbance, fear, and sorrow, and a sense of missing support and feeling insufficiently prepared for leaving care were also evident in their answers. Both the focus groups and surveys suggest that the biggest concern with the independence of young people leaving alternative care is financial stability. Several recommendations for ways to influence the system in order to improve outcomes for young people are made.
\end{abstract}

Keywords: alternative care, kinship foster care, professional foster care, emancipation, resilience

Anita Burgund Isakov $\mathrm{PhD}$ (corresponding author) is an assistant professor in the Faculty of Political Sciences, Department of Social Policy and Social Work, University of Belgrade, Jove Ilica 165, Belgrade. Email: anita.burgund@fpn.bg.ac.rs

Jasna Hrnčić $\mathrm{PhD}$ is an associate professor in the Faculty of Political Sciences, Department of Social Policy and Social Work, University of Belgrade, Jove Ilica 165, Belgrade. Email: jasna.hrncic@fpn.bg.ac.rs 
International Journal of Child, Youth and Family Studies (2018) 9(1): 83-107

A considerable number of children in Serbia are in care because of a lack of adequate parental care or adoption possibilities. The social welfare system in Serbia places, on average, 8 out of 10,000 children into care (Žegarac, 2014a). There were 6,088 children in care in 2015; 975 entered care that year, and, of these, 851 entered foster care, and 124 entered residential care (RZSZ, 2016).

The number of children entering the social care system increased by $19.7 \%$ in 2015 , even as the number of children in the general population declined by $0.8 \%$ due to demographic aging (RZSZ, 2016). The increase in children in care was seen especially in children from 0 to 2 years old (Žegarac, 2014b). Whereas in other countries youth typically leave alternative care between 16 and 18 years of age (Stein, 2006), in Serbia youth rarely have a chance to leave care before 18 (Burgund \& Žegarac, 2014; Žegarac, 2014a). Domestic research by the Centre for Social Work ${ }^{1}$ (Žegarac, 2014b) showed that about $75 \%$ of the 347 youth in care included in the research were not adequately prepared for leaving alternative care.

Youth leave alternative care at an age when most of their peers are still in the parental home (Stein, 2006). Most recent research has been focused on identifying the needs of young people at the moment of leaving alternative care (Montgomery, Donkoh, \& Underhill, 2006; Stein, 2006; Majstorovic, 2009), while the process of youth independence has rarely been analysed. Maunders, Liddell, Liddell, and Green (1999) described three phases of the process of leaving care: preparation, transition, and emancipation. Preparation may be lacking, as the protection that young people in alternative care receive from the social welfare system seems to make them passive (Burgund \& Žegarac, 2014). When they reach the age of 16 to 18, possibly after years in care, they often lose the protection and assistance of the social welfare system (Stein, 2006). Even when they encounter difficulties after leaving care, they do not usually have the option to return to the previous placement or a way to receive the help they need (Dixon $\&$ Stein, 2005). They are denied the psychological space that would allow them to face the challenges of independence as do their peers who live with their families - "Their path to adulthood is accelerated and compressed" (Stein, 2005, p. 10).

Stein (2006) suggested possible outcomes of such independence, dividing youth leaving care into those who are moving on, those who are merely surviving, and those who are becoming victims. Tweddle (2005) summarised research findings on predictors of successful emancipation outcomes: having successfully completed secondary school, the ability and ambition to continue their education, having self-care and household skills, minimal problems in education, the absence of substance abuse, and having been able to participate in decisions related to their preparation for emancipation. A longitudinal study of leaving care in Israel has shown that the sense of readiness to leave care was the greatest predictor of the experience of self-efficacy (Refaeli, 2014).

\footnotetext{
${ }^{1}$ The Centre for Social Work is a government agency providing social welfare and care for children, youth, and adults in need.
} 
International Journal of Child, Youth and Family Studies (2018) 9(1): 83-107

Health issues can reduce the likelihood of developing positive identity and can interfere with the ability to cope with the challenges presented by the transition from care to adult emancipated life (Stein, 2006). On the other hand, a positive perception of the future gives a sense of hope crucial for overcoming those challenges (Stein, 2009).

Stein (2005) summarises the main factors that affect resilience in young people who have left alternative care: the stability of the placement during care, whether they had a chance to develop a positive identity, the achieved level of education and participation, whether they had some preparation for leaving care, and what quality of life they achieved after leaving care.

\section{Present Study}

The process of preparing young people for leaving alternative care is not sufficiently studied in Serbia. The focus of this research is on the perspectives and opinions of youth in order to give them a voice and understand their perspective, encourage them, and foster their resilience.

Accordingly, the general aim of this research is to analyse the preparedness for emancipation of youth leaving alternative care in Serbia. The specific objectives of the research are: (a) to analyse the preparedness for emancipation of young people in alternative care in the process of becoming independent, and (b) to analyse the differences in preparedness of young people in Serbia to leave alternative care with regard to the type of placement (kinship, foster, or residential).

The criterion variable of this research, preparedness for independence, is defined by the following indicators: stability of placement in care, state of general and mental health, success and aspirations in schooling, social support, life skills (e.g., self-care and housekeeping) and social skills, orientation toward emancipation, and perception of the future. The predictor variable, type of placement, can be kinship, foster, or residential.

\section{Method}

In this study, both quantitative and qualitative approaches have been applied. Data for quantitative analysis were collected by questionnaires, which provided information on the presence of the indicators among the youth in our sample. Data for qualitative analysis were gathered in focus groups, which enable a more detailed description of a phenomenon and provide insights into its quality through dialogue (Đurić, 2005). Such a combined methodology is most useful when there is a need for generalisation of qualitative findings, as it provides access to the issue from different viewpoints, and allows its elaboration, qualification, and construction (Creswell, 2003). 
International Journal of Child, Youth and Family Studies (2018) 9(1): 83-107

\section{Sample}

The sample for the quantitative research consisted of 151 young people leaving alternative care in Serbia, ranging in age from 16 to 22 years $(M=18, S D=1.78)$, and representing both genders (females $n=76,50.3 \%$ ). Most had been placed in professional foster care $(n=86,57.0 \%$ of the sample, $54.7 \%$ boys and $59.2 \%$ girls), fewer in residential care ( $n=36,23.8 \%$ of the sample, $26.7 \%$ boys and $21.1 \%$ girls), and fewer still in kinship foster care ( $n=27,17.9 \%$ of the sample, $17.3 \%$ boys and $18.4 \%$ girls). Placement data were missing for two persons. All available youth aged 16 to 22 from centres for family placement in Serbia were included, as well as youth in residential care in the Centre for Protection of Infants, Children and Youth in Belgrade. The sample for qualitative research consisted of all of the young people from the above sample who voluntarily applied for and participated in one of five focus groups. Altogether there were 26 focus group participants, from 16 to 22 years of age, with 16 in either foster care or kinship care ( 8 girls and 8 boys) and 10 in residential care ( 3 girls and 7 boys). The focus groups averaged five participants each.

\section{Data Collection Tools and Research Procedure}

The Data Collection Protocol for Youth in Alternative Care (DCPYAC) was prepared for the purposes of the broader research on the same sample. Only two questions, regarding psychiatric diagnosis and abuse of psychoactive substances, were used in this paper. These data were collected from official records on young people in care.

All indicators of youth's preparedness while still in care were identified and mapped in earlier research. They are operationalised in the Questionnaire on Leaving Alternative Care Factors For Youth (QLACFY) that was completed by young people leaving alternative care. Besides demographic data (gender, age, type of placement), the part of the questionnaire used in this paper is the operationalisation of indicators of preparedness listed above, organised in seven topics: stability of alternative care placements (three questions); general and mental health status (two closed-ended questions); success (two closed-ended questions) and aspiration in schooling (four questions); needed and available social support (seven closed-ended questions); life and social skills (13 items about self-care, household skills, and obtaining social support); relation toward emancipation (four closed-ended questions); and, perception of the future (one closedended question).

The defined topics in focus groups were: preparedness for emancipation, worries and fears regarding emancipation (two questions), and available support and asking for support during preparedness for leaving care.

All youth involved in the study were informed about confidentiality, and all gave written informed consent to be involved in the research. Participants filled in the questionnaires independently or with the help of trained interviewers. The average duration of focus groups was 
International Journal of Child, Youth and Family Studies (2018) 9(1): 83-107

approximately 75 minutes. The study was conducted in Serbian; materials and results have been translated into English by the author for this paper.

\section{Data Processing}

Answers to the open-ended questions in questionnaires DCPYAC and QLACFY were first coded according to the most frequent answers; then all answers were entered in a database. Data were statistically processed by the SPSS 22 program, and the analyses implemented were Pearson's chi-squared test, a one-way analysis of variance (ANOVA), and a t-test.

Responses of the young people in the focus groups were coded by gender and number of participants: each response has the code "I" (respondent), "m" or " $\mathrm{f}$ " (gender), and the serial number of the respondents (e.g., "Im13"). Data were processed by thematic analysis.

\section{Results}

\section{Time Spent in Care and Stability of Placement}

On average, our participants had spent 7 years and 8 months in care $(M=93.66$ months, $S D=65.184$ ). The range of time spent in placement varied from 1 month to 21 years. Only $5.3 \%$ had spent less than 6 months in care, 9.3\% had been in care from 6 months to a year, 32.8\% from 2 to 6 years, $25.2 \%$ between 6 and 10 years, and 32.5\% had spent more than 10 years in care. There were no significant differences between groups by type of placement $(F[2,141]=2.073, \mathrm{p}$ $=.130)$.

Most participants had been in only one placement $(64.9 \%, n=98)$, three times more than the number that had had two placements $(21.2 \%, n=32)$, while $7.9 \%$ had had three or more placements $(n=12)$. There were five $(3.3 \%)$ with three placements, four $(2.6 \%)$ with four placements, and three (2.0\%) with five placements. Data were missing for $6.0 \%$ of youth $(n=9$, $M=1.47, S D=0.869)$. The one-way ANOVA showed significant differences between the types of placements (Table 1). Young people from residential care had a significantly higher number of placements than those in foster care $(t[112]=3.099, p=.003)$ and kinship care $(t[59]=4.537$, $p<.001)$, and those in foster care had a significantly greater number of placements than those in kinship care $(t[103]=2.922, p=.004)$.

Table 1 Significant Differences in Number of Placements by Placement Type

\begin{tabular}{|c|c|c|c|c|c|c|c|c|c|}
\hline \multirow{3}{*}{ Variable } & \multicolumn{6}{|c|}{ Type of current placement } & \multirow{2}{*}{\multicolumn{3}{|c|}{ Significance of differences }} \\
\hline & \multicolumn{2}{|c|}{$\begin{array}{c}\text { Foster care } \\
(n=79)\end{array}$} & \multicolumn{2}{|c|}{$\begin{array}{c}\text { Kinship care } \\
(n=26)\end{array}$} & \multicolumn{2}{|c|}{$\begin{array}{c}\text { Residential care } \\
(n=35)\end{array}$} & & & \\
\hline & $M$ & $S D$ & $M$ & $S D$ & $M$ & $S D$ & $F$ & $d f$ & Sig. \\
\hline $\begin{array}{l}\text { Number of } \\
\text { placements }\end{array}$ & 1.35 & 699 & 1.08 & .272 & 2.03 & 1.200 & 12.323 & $\begin{array}{c}2 \\
137\end{array}$ & .000 \\
\hline
\end{tabular}


International Journal of Child, Youth and Family Studies (2018) 9(1): 83-107

\section{Health}

Health condition - self-assessment: Most participants assessed themselves as very good, both for their general health $(57.5 \%, n=84)$, as shown in Table 2, and for their mental health $(64.7 \%, n=95)$, as shown in Table 3 .

Table 2 Self-Assessment of General Health

\begin{tabular}{|c|c|c|c|c|c|c|c|c|}
\hline \multirow{3}{*}{ Assessment } & \multicolumn{6}{|c|}{ Type of current placement } & \multirow{2}{*}{\multicolumn{2}{|c|}{ Total }} \\
\hline & \multicolumn{2}{|c|}{ Foster care } & \multicolumn{2}{|c|}{ Kinship care } & \multicolumn{2}{|c|}{ Residential care } & & \\
\hline & $n$ & $\%$ & $n$ & $\%$ & $n$ & $\%$ & $n$ & $\%$ \\
\hline Very good & 59 & 70.2 & 15 & 55.6 & 10 & 28.6 & 84 & 57.5 \\
\hline Good & 20 & 23.8 & 11 & 40.7 & 22 & 62.9 & 53 & 36.3 \\
\hline Not so good & 4 & 4.8 & 1 & 3.7 & 3 & 8.6 & 8 & 5.5 \\
\hline Bad & 1 & 1.2 & 0 & 0.0 & 0 & 0.0 & 1 & 0.7 \\
\hline Total & 84 & 100.0 & 27 & 100.0 & 35 & 100.0 & 146 & 100.0 \\
\hline \multirow{2}{*}{$M$ and SD } & $M$ & $S D$ & $M$ & $S D$ & $M$ & $S D$ & $M$ & $S D$ \\
\hline & 2.63 & 0.636 & 2.52 & 0.560 & 2.20 & 0.584 & 2.51 & 0.635 \\
\hline
\end{tabular}

Table 3 Self-Assessment of Mental Health

\begin{tabular}{|c|c|c|c|c|c|c|c|c|}
\hline \multirow{3}{*}{ Assessment } & \multicolumn{6}{|c|}{ Type of current placement } & \multirow{2}{*}{\multicolumn{2}{|c|}{ Total }} \\
\hline & \multicolumn{2}{|c|}{ Foster care } & \multicolumn{2}{|c|}{ Kinship care } & \multicolumn{2}{|c|}{ Residential care } & & \\
\hline & $n$ & $\%$ & $n$ & $\%$ & $n$ & $\%$ & $n$ & $\%$ \\
\hline Very good & 59 & 68.6 & 17 & 63.0 & 19 & 55.9 & 95 & 64.7 \\
\hline Good & 24 & 27.9 & 10 & 37.0 & 12 & 35.3 & 46 & 30.9 \\
\hline Not so good & 3 & 3.5 & 0 & 0.0 & 3 & 8.8 & 6 & 4.1 \\
\hline Bad & 0 & 0.0 & 0 & 0.0 & 0 & 0.0 & 0 & 0.0 \\
\hline Total & 86 & 100.0 & 27 & 100.0 & 34 & 100.0 & 147 & 100.0 \\
\hline \multirow{2}{*}{$M$ and SD } & $M$ & $S D$ & $M$ & $S D$ & $M$ & $S D$ & $M$ & $S D$ \\
\hline & 2.65 & 0.548 & 2.57 & 0.492 & 2.47 & 0.662 & 2.61 & 0.568 \\
\hline
\end{tabular}

Participants in foster care most frequently assessed their general and mental health as very good, while young people in residential care most frequently assessed their general health as good and mental health as very good (Tables 2 and 3). Those in kinship care usually assessed their overall health as very good, and their mental health as good, while no one in this category assessed their mental health as very good. The one-way ANOVA showed that those in residential care assessed their general health condition less positively $(F[2,143]=6.093, p=.003)$ than those in either foster $(t[117]=3.448, p=.001)$ or kinship care $(t[60]=2.136, p=.037)$. There were no significant differences in mental health by type of placement $(F[2,144]=1.266, p=$ $.285)$.

Mental condition from records: Data from DCPYAC showed that substance abuse was recorded in $4.4 \%(n=7)$ of cases, with $3.3 \%(n=5)$ having abused cannabis and $1.3 \%(n=2)$ alcohol. A psychiatric diagnosis had been recorded for $11.9 \%(n=18)$ of our participants, with 
International Journal of Child, Youth and Family Studies (2018) 9(1): 83-107

mental disability in 5.3\% $(n=8)$ of cases, organic mental disorders and behavioural disorders in $3.3 \%(n=5)$, and multiple difficulties in only one case $(0.7 \%)$.

\section{Schooling}

Success in schooling: The vast majority of respondents were regularly attending school (94.7\%, $n=143)$ at the time of data collection; $10.6 \%$ of them $(n=16)$ had work, with $2.6 \%$ $(n=4)$ having full-time work. Most were attending high school $(37.7 \%, n=57)$ or craft school (baking, butchery, hairdressing, etc.; 33.3\%, $n=50)$. Some (8.6\%; $n=13$ ) were attending university, and $6.6 \%(n=10)$ attended a school for students with special needs. One person had completed high school $(0.7 \%)$ without going on to further studies. The most frequent result in school, based on file reviews, was very good success $(32.7 \%, n=49)$, while $25.3 \%(n=38)$ had good success, and $22.0 \%(n=33)$ were rated as excellent; sufficient success $(8.0 \%, n=12)$ and insufficient success $(5.3 \%, n=8)$ were rare. There was no significant difference in school success by type of care $(F[2,133]=0.52, p=.95)$.

Aspirations: More than two thirds of our respondents $(70.2 \%, n=106)$ indicated that they were satisfied with their school success, while one quarter $(24.5 \%, n=37)$ were dissatisfied. They did not show significant differences by the type of placement (Pearson's chisquared[8] $=12.858, p=.117)$. A little over three quarters were planning to continue their education $(76.2 \%, n=115)$, while $17.2 \%(n=26)$ did not have that intention. There were no significant differences by the type of placement on this variable (Pearson's chi-squared[2] = $0.231, p=.891)$.

The vast majority $(83.4 \%, n=126)$ felt that they had chosen the school which they attended, while $9.9 \%(n=15)$ felt they hadn't chosen the school they attended, and $8.1 \%(n=$ 12) did not answer this question. There were no significant differences by the type of placement (Pearson's chi-squared[6] $=9.538, p=.146$ ). The most frequent reasons young people offered for not choosing the school they attended was that someone else had made a decision for them ( $n=4$; answers: "Centre for Social Work has made a decision", "Because I was not even asked for my opinion") and poor school performance $(n=2)$.

The importance that participants placed on their aspirations for education and employment was evaluated by their answers to the question, "What are your wishes for the future?". There were nine closed-ended choices and one open-ended choice ("other") offered, with the possibility of multiple responses. Two of the answers, one relating to education ("finish school") and the other to career ("get a job"), considered professional aspiration. The most common responses were that they wanted to find a job $(87.3 \%, n=131)$ and to finish school $(84.7 \%, n=127)$. There were no significant differences in the aspirations of respondents for employment in relation to the type of care (Pearson's chi-squared[2] $=1.040, p=.594$ ), while there were marginally significant differences in aspiration to finish school (Pearson's chisquared[2] $=4.882, p=.087)$, which was more frequently reported by those in foster care $(54.4 \%)$ than those in kinship $(19.2 \%)$ or residential care $(26.4 \%)$. 
International Journal of Child, Youth and Family Studies (2018) 9(1): 83-107

\section{Social Support}

Evaluation of support networks was based on the responses to a few groups of questions.

Sources of support: The first question group targeted sources of support and the extent to which help was available (see Table 4), answered on a four-point scale that ranged from 1 ( $I$ do not have that person) to 4 (significant help). The number of responses on items varied from $62.3 \%(n=94)$ to $90.7 \%(n=137)$ out of a total sample of 151 . The lowest response rate $(62.3 \%)$ was to the item "residential care staff", perhaps because many participants in family placement had no contact with them. Most often participants stated that they receive support from friends $(88.7 \%)$, foster parents $(81.8 \%)$, case managers $(80.5 \%)$, foster care counsellors (76.2\%), and siblings $(75.6 \%)$. The least frequent was help from residential care staff $(36.1 \%)$ and parents $(41.5 \%)$. Teachers were assessed as help providers in almost two thirds of cases $(65.5 \%)$; relatives (i.e., extended family, not parents or siblings) in more than half of the cases (57.2\%). Significant help is provided most frequently to participants in family care (foster and kinship): a vast majority of them receive it from foster parents $(90.1 \%)$ and almost two thirds (62.4\%) from foster care counsellors. On the other hand, young people in residential care less frequently reported significant help from residential care staff $(43.8 \%)$. About one half of participants recognized that they have significant help from siblings, and two fifths of them from friends and case managers, while other providers were less acknowledged. For the most part, the results concerning the persons missing from the lives of young people (I don't have that person) were expected. Most frequently, the missing family members were parents, followed by relatives. Respondents' identification of the professionals missing from their support systems varied according to the type of placement. An unexpected result was that $17.7 \%$ of participants reported not having teachers in their lives, although only 5.3\% weren't attending school at the time of data collection. This might be the result of the custom in some parts of Serbia of referring to high school teachers as "professors". Although only $7.1 \%(n=8)$ of participants reported that they didn't have a case manager, this is still an unexpected result because they all should have a case manager active in their lives.

There were significant differences in the amount of support reported by our participants in different types of care on six items: relatives (Pearson's chi-squared[6] $=18.688, p=.005, C=$ .381 ), case managers (Pearson's chi-squared[6] $=13.425, p=.037, C=.327$ ), teachers (Pearson's chi-squared[6] $=18.398, p=.006, C=.373$ ), residential care staff (Pearson's chisquared $[6]=38.792, p<.001, C=.540$ ), foster parents (Pearson's chi-squared[8] $=119.632$, $p<.001, C=.685$ ), and foster care counsellors (Pearson's chi-squared[6] $=86.520, p<.001$, $C=.652)$. See Table 4 . 
International Journal of Child, Youth and Family Studies (2018) 9(1): 83-107

Table 4 Perceived Level of Support by Type of Placement

\begin{tabular}{|c|c|c|c|c|c|c|c|c|c|}
\hline \multirow{3}{*}{$\begin{array}{c}\text { Source of } \\
\text { support }\end{array}$} & \multirow{3}{*}{ Level of support } & \multicolumn{6}{|c|}{ Type of current placement } & \multirow{2}{*}{\multicolumn{2}{|c|}{ Total }} \\
\hline & & \multicolumn{2}{|c|}{ Foster care } & \multicolumn{2}{|c|}{ Kinship care } & \multicolumn{2}{|c|}{ Residential care } & & \\
\hline & & $n$ & $\%$ & $n$ & $\%$ & $n$ & $\%$ & $n$ & $\%$ \\
\hline \multirow[t]{5}{*}{ Parents } & Significant help & 17 & 24.6 & 5 & 25.0 & 7 & 25.0 & 29 & 24.6 \\
\hline & Some help & 12 & 17.4 & 4 & 20.0 & 4 & 14.3 & 20 & 16.9 \\
\hline & Not helping me & 19 & 27.5 & 0 & 0.0 & 7 & 25.0 & 26 & 22.0 \\
\hline & Don't have that person & 21 & 30.4 & 11 & 55.0 & 10 & 35.7 & 43 & 36.4 \\
\hline & Total & 69 & 100.0 & 20 & 100.0 & 28 & 100.0 & 118 & 100.0 \\
\hline \multirow[t]{5}{*}{ Relatives } & Significant help & 10 & 17.5 & 11 & 47.8 & 8 & 26.7 & 30 & 26.8 \\
\hline & Some help & 18 & 31.6 & 10 & 43.5 & 5 & 16.7 & 34 & 30.4 \\
\hline & Not helping me & 13 & 22.8 & 2 & 8.7 & 10 & 33.3 & 25 & 22.3 \\
\hline & Don't have that person & 16 & 28.1 & 0 & 0.0 & 7 & 23.3 & 23 & 20.5 \\
\hline & Total & 57 & 100.0 & 23 & 100.0 & 30 & 100.0 & 112 & 100.0 \\
\hline \multirow[t]{5}{*}{ Sibling } & Significant help & 33 & 45.2 & 17 & 73.9 & 15 & 45.5 & 66 & 50.4 \\
\hline & Some help & 19 & 26.0 & 4 & 17.4 & 9 & 27.3 & 33 & 25.2 \\
\hline & Not helping me & 14 & 19.2 & 2 & 8.7 & 4 & 12.1 & 20 & 15.3 \\
\hline & Don't have that person & 7 & 9.6 & 0 & 0.0 & 5 & 15.2 & 12 & 9.2 \\
\hline & Total & 73 & 100.0 & 23 & 100.0 & 33 & 100.0 & 131 & 100.0 \\
\hline \multirow[t]{5}{*}{ Friends } & Significant help & 31 & 42.5 & 9 & 37.5 & 13 & 39.4 & 56 & 42.1 \\
\hline & Some help & 35 & 47.9 & 13 & 54.2 & 14 & 42.4 & 62 & 46.6 \\
\hline & Not helping me & 4 & 5.5 & 2 & 8.3 & 3 & 9.1 & 9 & 6.8 \\
\hline & Don't have that person & 3 & 4.1 & 0 & 0.0 & 3 & 9.1 & 6 & 4.5 \\
\hline & Total & 73 & 100.0 & 24 & 100.0 & 33 & 100.0 & 133 & 100.0 \\
\hline \multirow{5}{*}{$\begin{array}{l}\text { Case } \\
\text { managers }\end{array}$} & Significant help & 27 & 44.3 & 5 & 25.0 & 12 & 38.7 & 45 & 39.8 \\
\hline & Some help & 27 & 44.3 & 11 & 55.0 & 8 & 25.8 & 46 & 40.7 \\
\hline & Not helping me & 4 & 6.6 & 4 & 20.0 & 6 & 19.4 & 14 & 12.4 \\
\hline & Don't have that person & 3 & 4.9 & 0 & 0.0 & 5 & 16.1 & 8 & 7.1 \\
\hline & Total & 61 & 100.0 & 20 & 100.0 & 31 & 100.0 & 113 & 100.0 \\
\hline \multirow[t]{5}{*}{ Teachers } & Significant help & 15 & 25.0 & 5 & 22.7 & 11 & 37.9 & 32 & 28.3 \\
\hline & Some help & 24 & 40.0 & 11 & 50.0 & 6 & 20.7 & 42 & 37.2 \\
\hline & Not helping me & 14 & 23.3 & 4 & 18.2 & 1 & 3.4 & 19 & 16.8 \\
\hline & Don't have that person & 7 & 11.7 & 2 & 9.1 & 11 & 37.9 & 20 & 17.7 \\
\hline & Total & 60 & 100.0 & 22 & 100.0 & 29 & 100.0 & 113 & 100.0 \\
\hline \multirow{5}{*}{$\begin{array}{l}\text { Residential } \\
\text { care staff }\end{array}$} & Significant help & 7 & 14.3 & 0 & 0.0 & 14 & 43.8 & 21 & 22.3 \\
\hline & Some help & 3 & 6.1 & 0 & 0.0 & 10 & 31.2 & 13 & 13.8 \\
\hline & Not helping me & 6 & 12.2 & 0 & 0.0 & 3 & 9.4 & 9 & 9.6 \\
\hline & Don't have that person & 33 & 67.3 & 13 & 100.0 & 5 & 15.6 & 51 & 54.3 \\
\hline & Total & 49 & 100.0 & 13 & 100.0 & 32 & 100.0 & 94 & 100.0 \\
\hline \multirow{5}{*}{$\begin{array}{l}\text { Foster } \\
\text { parents }\end{array}$} & Significant help & 77 & 90.6 & 23 & 88.5 & 0 & 0.0 & 102 & 74.5 \\
\hline & Some help & 6 & 7.1 & 3 & 11.5 & 1 & 4.2 & 10 & 7.3 \\
\hline & Not helping me & 1 & 1.2 & 0 & 0.0 & 1 & 4.2 & 2 & 1.5 \\
\hline & Don't have that person & 1 & 1.2 & 0 & 0.0 & 22 & 91.7 & 23 & 16.8 \\
\hline & Total & 85 & 100.0 & 26 & 100.0 & 24 & 100.0 & 137 & 100.0 \\
\hline \multirow{5}{*}{$\begin{array}{l}\text { Foster care } \\
\text { counsellors }\end{array}$} & Significant help & 46 & 65.7 & 12 & 52.2 & 1 & 4.2 & 60 & 50.8 \\
\hline & Some help & 18 & 25.7 & 11 & 47.8 & 1 & 4.2 & 30 & 25.4 \\
\hline & Not helping me & 3 & 4.3 & 0 & 0.0 & 2 & 8.3 & 5 & 4.2 \\
\hline & Don't have that person & 3 & 4.3 & 0 & 0.0 & 20 & 83.3 & 23 & 19.5 \\
\hline & Total & 70 & 100.0 & 23 & 100.0 & 24 & 100.0 & 118 & 100.0 \\
\hline
\end{tabular}


International Journal of Child, Youth and Family Studies (2018) 9(1): 83-107

As shown in Table 4, help from relatives was rated highest by participants in kinship care $(91.3 \%)$ and lowest by those in residential care $(43.4 \%)$. Help from case managers was rated highest by young people in foster care $(88.6 \%)$ and lowest by those in residential care $(64.5 \%)$, while help from teachers was rated highest by young people in kinship care $(72.7 \%)$ and lowest by those in residential care (58.6\%). In assessing help from residential staff, the highest scores were noted by young people from residential care $(75.5 \%)$; considerably fewer of those in foster care considered that they received such help (20.4\%) while, as would be expected, young people from kinship care indicated that they did not have any residential care people in their lives. Likewise, the significant differences for foster parents and foster care counsellors were due to the lack of such a person in the lives of most young people in residential care. Significant differences by type of placement were not found for parents, siblings, or friends.

The results of focus group discussions: All participants in the focus groups recognised the importance of getting support for becoming independent and for overcoming future challenges. They recognised who provided support for them; often it was only one person. For example, one participant said, "Only the manager of the institution will be the one that will take care of me, I know that she will take my phone number and call me to ask how I am and whether I manage" (Im4). Participants generally perceived every support as positive, making such statements as: "I have a case manager and a guardian, we never had a problem and we're in good relations" (Im6).

Needed and received support in different areas: Respondents answered the closedended question "In which areas do you need help?" by circling one or more of six possible answers. As shown in Table 5, the most frequent answers were job (61.6\%), finance (56.3\%), and housing $(37.7 \%)$, followed by counselling and support $(35.1 \%)$, education $(29.8 \%)$, and health $(9.3 \%)$.

When asked to specify the areas in which they have received substantial assistance, with six possible answers, Table 5 shows that participants most commonly circled advice (62.0\%), followed by the completion of school education (52.1\%), material support (27.5\%), and establishing contact with family $(19.0 \%)$. They reported receiving the least help with finding a job $(9.9 \%)$ and an apartment $(7.7 \%)$. Of the eight young people $(7.7 \%)$ who chose "Other", three were not leaving care $(2.1 \%)$, four did not get any help at all $(2.8 \%)$, and one got help with the furniture for the apartment she would live in after leaving alternative care $(0.7 \%)$.

Significant differences by type of placement were confirmed for needed help in finance (Pearson's chi-squared[2] $=6.283, p=.043$ ) and housing (Pearson's chi-squared[2] $=16.731, p$ $=.001$ ), with those in kinship care reporting the least need in these areas. As for receiving substantial help, there were no significant differences by the type of placement in any category. 
International Journal of Child, Youth and Family Studies (2018) 9(1): 83-107

Table 5 Assessment of Needed and Received Assistance by Different Areas

\begin{tabular}{lccl|lcrc}
\hline \multicolumn{5}{c|}{ Needed help } & \multicolumn{4}{c}{ Received help } \\
\hline Needed help in: & $\mathrm{N}_{\mathrm{p}}{ }^{*}$ & $\%_{\mathrm{p}}{ }^{* *}$ & $\mathrm{~N}$ total & Received substantial help in: & $\mathrm{N}_{\mathrm{p}}{ }^{*}$ & $\%_{\mathrm{p}} * *$ & $\mathrm{~N}$ total \\
\hline Finance & 85 & 56.3 & 148 & Material support & 39 & 27.5 & 142 \\
Housing & 57 & 37.7 & 148 & Finding apartment & 11 & 7.7 & 142 \\
Schooling & 45 & 29.8 & 148 & In finishing school & 74 & 52.1 & 142 \\
Job seeking & 93 & 61.6 & 148 & Finding a job & 14 & 9.9 & 142 \\
Counselling and support & 53 & 35.1 & 148 & Advice & 88 & 62.0 & 142 \\
Health & 14 & 9.3 & 148 & Contacting a family & 27 & 19.0 & 142 \\
Other & 1 & 0.7 & 148 & Other & 8 & 5.6 & 142 \\
\hline
\end{tabular}

$* \mathrm{~N}_{\mathrm{p}}$ - Number of positive answers; $* * \% \%_{\mathrm{p}}$-percentage of positive answers

Social backing: There were four questions about who youth felt able to rely on in case of need, with responses on a four-point Likert scale (Table 6). Most participants indicated that they have an adult of trust whom they could rely on when needed $(91.0 \% ; 72.2 \%$ indicated "completely true"); slightly fewer said that they could rely on their foster parents or caregivers (86.7\%; 62.2\% responded "completely true"); over three quarters would count on their friends (79.0\%; 35.5\% responded "completely true"), while the percentage who felt they could count on their families was lowest $(66.6 \% ; 44.9 \%$ responded "completely true").

Table 6 Social Backup — Self Assessment

\begin{tabular}{|c|c|c|c|c|c|c|c|c|c|}
\hline \multirow[t]{2}{*}{ Social backup } & \multirow[t]{2}{*}{ Answers } & \multicolumn{2}{|c|}{ Foster care } & \multicolumn{2}{|c|}{ Kinship care } & \multicolumn{2}{|c|}{$\begin{array}{l}\text { Residential } \\
\text { care }\end{array}$} & \multicolumn{2}{|c|}{ Total } \\
\hline & & $n$ & $\%$ & $n$ & $\%$ & $n$ & $\%$ & $N$ & $\%$ \\
\hline \multirow{5}{*}{$\begin{array}{l}\text { I have a trusted adult } \\
\text { on whom I can rely } \\
\text { when I need to }\end{array}$} & Completely false & 8 & 9.5 & 0 & 0.0 & 3 & 9.1 & 11 & 7.6 \\
\hline & Mainly not true & 0 & 0.0 & 0 & 0.0 & 2 & 6.1 & 2 & 1.4 \\
\hline & Mainly true & 14 & 16. 7 & 4 & 14.8 & 9 & 27.3 & 27 & 18.8 \\
\hline & Completely true & 62 & 73.8 & 23 & 85.2 & 19 & 57.6 & 104 & 72.2 \\
\hline & Total & 84 & 100.0 & 27 & 100.0 & 33 & 100.0 & 144 & 100.0 \\
\hline \multirow{5}{*}{$\begin{array}{l}\text { I can count on my } \\
\text { family members }\end{array}$} & Completely false & 18 & 23.1 & 1 & 3.7 & 7 & 20.6 & 26 & 18.8 \\
\hline & Mainly not true & 11 & 14.1 & 0 & 0.0 & 9 & 26.5 & 20 & 14.5 \\
\hline & Mainly true & 18 & 23.1 & 3 & 11.1 & 9 & 26.5 & 30 & 21.7 \\
\hline & Completely true & 31 & 39.7 & 23 & 85.2 & 9 & 26.5 & 62 & 44.9 \\
\hline & Total & 78 & 100.0 & 27 & 100 & 34 & 100.0 & 138 & 100.0 \\
\hline \multirow{5}{*}{$\begin{array}{l}\text { I can count on my } \\
\text { foster } \\
\text { parents/caregivers }\end{array}$} & Completely false & 7 & 8.3 & 0 & 0.0 & 6 & 18.8 & 13 & 9.1 \\
\hline & Mainly not true & 2 & 2.4 & 0 & 0.0 & 4 & 12.5 & 6 & 4.2 \\
\hline & Mainly true & 16 & 19.0 & 6 & 22.2 & 13 & 40.6 & 35 & 24.5 \\
\hline & Completely true & 59 & 70.2 & 21 & 77.8 & 9 & 28.1 & 89 & 62.2 \\
\hline & Total & 84 & 100.0 & 27 & 100.0 & 32 & 100.0 & 143 & 100.0 \\
\hline \multirow{5}{*}{$\begin{array}{l}\text { I can count on my } \\
\text { friends }\end{array}$} & Completely false & 7 & 8.8 & 2 & 7.4 & 6 & 19.4 & 15 & 10.9 \\
\hline & Mainly not true & 12 & 15.0 & 0 & 0.0 & 2 & 6.5 & 14 & 10.1 \\
\hline & Mainly true & 29 & 36.2 & 11 & 40.7 & 20 & 64.5 & 60 & 43.5 \\
\hline & Completely true & 32 & 40.0 & 14 & 51.8 & 3 & 9.7 & 49 & 35.5 \\
\hline & Total & 80 & 100.0 & 27 & 100.0 & 31 & 100.0 & 138 & 100.0 \\
\hline
\end{tabular}


International Journal of Child, Youth and Family Studies (2018) 9(1): 83-107

A one-way ANOVA showed significant differences between types of alternative care in three of the four social backup items: family members, foster parents or caregivers, and friends (Table 7). On the fourth item ("I have a trusted adult on whom I can rely when I need to") the type of placement had marginal significance, with higher results from youth in kinship care.

Further analysis by simple $t$-test showed that participants in kinship care assessed significantly more often than those in residential $(t[47.3]=5.814, p<.001)$ and foster care $(t[100.6]=6.197, p<.001)$ that they could rely on family members. These participants reported feeling that they could rely on foster parents or caretakers significantly more than did young people in foster $(t[41.9]=4.839, p<.001)$ and residential care $(t[94.0]=2.085, p=.040)$. Those in foster care assessed that they counted on their foster parents or residental staff significantly more than did those in residential care $(t[114]=3.710, p<.001)$. Those in residential care assessed that they could rely on friends significantly less than did those in kinship $(t[56]=3.799$, $p<.001)$ and foster care $(t[109]=2.158, p=.033)$. In all cases, the biggest difference was between the young people in kinship care, who had the highest scores, and those in residential care, who had the lowest.

Table 7 Significant Differences in Social Backups of Youth by Type of Care

\begin{tabular}{|c|c|c|c|c|c|c|c|c|c|}
\hline \multirow{3}{*}{ Social backups } & \multicolumn{6}{|c|}{ Type of care } & \multirow{2}{*}{\multicolumn{3}{|c|}{ Significant differences }} \\
\hline & \multicolumn{2}{|c|}{ Foster care } & \multicolumn{2}{|c|}{ Kinship care } & \multicolumn{2}{|c|}{ Residential care } & & & \\
\hline & $M$ & $S D$ & $M$ & $S D$ & $M$ & $S D$ & $F$ & $d f$ & Sig. \\
\hline Grown up of trust & 3.55 & .910 & 3.85 & .362 & 3.33 & .957 & 2.781 & $\begin{array}{r}2 \\
141\end{array}$ & .065 \\
\hline Family members & 2.79 & 1.199 & 3.81 & .483 & 2.59 & 1.104 & 11.481 & $\begin{array}{r}2 \\
136\end{array}$ & .000 \\
\hline $\begin{array}{l}\text { Foster parents/ } \\
\text { social pedagogues }\end{array}$ & 3.51 & .898 & 3.78 & .424 & 2.78 & 1.070 & 11.211 & $\begin{array}{r}2 \\
140\end{array}$ & .000 \\
\hline Friends & 3.08 & .952 & 3.44 & .640 & 2.64 & .915 & 5.869 & $\begin{array}{r}2 \\
135 \\
\end{array}$ & .004 \\
\hline
\end{tabular}

The results of focus group discussions: Young people from residential care who were preparing for independence often mentioned their need to strengthen their skills and their selfconfidence, and how important that was for achieving success, especially in response to the stress and uncertainty that they would face during emancipation. For example, one participant said, "I have raised my confidence to such a level that whenever I talk to someone regarding my residential care or school, I am happy and I believe in myself" (If7). The alternative care system and its professionals were seen as providing material services and benefits to which the participants felt they were entitled. However, participants did not feel they received support or guidance from them as illustrated by the following conversation:

Q: "Would you ask someone from the Centre for Social Work to help you?"

A: "No, that would not have occurred to me, I do not believe that it would be helpful, they would hardly help us if we have left care" (If8). 
International Journal of Child, Youth and Family Studies (2018) 9(1): 83-107

\section{Living and Social Skills}

To the closed-ended question "Have you mastered the mentioned skills?", after which 13 skills were listed, youth answered on a four-point Likert scale. Housekeeping and money management skills, social skills, and self-care skills were included (Table 8).

The number of responses on items varied from 103 to 148 , out of a total sample of 151 . The lowest response rate $(68.2 \%)$ was to the item "I use protection during sexual intercourse", perhaps because many had not engaged in sexual relations. The highest response rate was $98.0 \%$ of the sample for the items "I eat healthily" and "I take care about personal hygiene". Some skills responses were mostly positive indicating that the skill was mastered; this was most often the case with youth in foster care (Table 8).

The young people in our sample most positively evaluated taking care of personal hygiene and their health. Nearly all believed that they had completely mastered these skills (97.3\% and 93.2\%), while significantly fewer considered that they ate healthy food (82.5\%), and still fewer indicated knowing how to cook $(72.2 \%)$. Not all had mastered skills related to spare time, with $78.8 \%$ reporting engaging in hobbies and $69.0 \%$ in sports.

The results in the social relations area showed that most participants managed to have friends $(94.4 \%)$ and to make new friends $(87.0 \%)$, while they found it more difficult to enter into dating partnerships $(71.9 \%)$. Most of those who indicated whether they use protection during sexual relations replied positively $(82.5 \%)$.

The one-way ANOVA showed significant differences between types of alternative care in two categories: eating healthily $(F[2,15]=0.515, p<.001)$ and taking care of health $(F[2,144]=4.098, p=.019)$. The differences reflect the significantly lower scores of particpants in residential care. Marginal significance was shown in "looking for help and information" $(F[2,142]=2.885, p=.059)$ with participants in residential care having the lowest scores and those in kinship care having the highest. 
International Journal of Child, Youth and Family Studies (2018) 9(1): 83-107

Table 8 Self-Assessment of Mastered Skills by The Type of Care

\begin{tabular}{|c|c|c|c|c|c|c|c|c|c|}
\hline \multirow{2}{*}{ Skill } & \multirow{2}{*}{ Answers } & \multicolumn{2}{|c|}{ Foster care } & \multicolumn{2}{|c|}{ Kinship care } & \multicolumn{2}{|c|}{ Residential care } & \multicolumn{2}{|c|}{ Total } \\
\hline & & $n$ & $\%$ & $n$ & $\%$ & $n$ & $\%$ & $n$ & $\%$ \\
\hline \multirow[t]{5}{*}{ I can cook } & Completely false & 9 & 11.4 & 2 & 7.4 & 4 & 11.8 & 15 & 10.7 \\
\hline & Mainly not true & 16 & 20.3 & 4 & 14.8 & 4 & 11.8 & 24 & 17.1 \\
\hline & Mainly true & 43 & 54.4 & 18 & 66.7 & 20 & 58.8 & 81 & 57.9 \\
\hline & Completely true & 11 & 13.9 & 3 & 11.1 & 6 & 17.6 & 20 & 14.3 \\
\hline & Total & 79 & 100 & 27 & 100 & 34 & 100 & 140 & 100 \\
\hline \multirow{5}{*}{$\begin{array}{l}\text { I can provide } \\
\text { everything for } \\
\text { maintenance }\end{array}$} & Completely false & 3 & 3.6 & 2 & 7.7 & 1 & 3.0 & 6 & 4.2 \\
\hline & Mainly not true & 1 & 1.2 & & 0 & 2 & 6.1 & 3 & 2.1 \\
\hline & Mainly true & 40 & 47.6 & 12 & 46.2 & 15 & 45.5 & 67 & 46.9 \\
\hline & Completely true & 40 & 47.6 & 12 & 46.2 & 15 & 45.5 & 67 & 46.9 \\
\hline & Total & 84 & 100.0 & 26 & 100 & 33 & 100.0 & 143 & 100.0 \\
\hline \multirow{5}{*}{$\begin{array}{l}\text { I can do money } \\
\text { management }\end{array}$} & Completely false & 8 & 9.4 & 5 & 18.5 & 2 & 5.9 & 15 & 10.3 \\
\hline & Mainly not true & 0 & 0 & 0 & 0 & 5 & 14.7 & 5 & 3.4 \\
\hline & Mainly true & 40 & 47.1 & 9 & 33.3 & 14 & 41.2 & 63 & 43.2 \\
\hline & Completely true & 37 & 43.5 & 13 & 48.1 & 13 & 38.2 & 63 & 43.2 \\
\hline & Total & 85 & 100.0 & 27 & 100.0 & 34 & 100 & 146 & 100.0 \\
\hline \multirow{5}{*}{$\begin{array}{l}\text { I take care } \\
\text { about } \\
\text { health }\end{array}$} & Completely false & 4 & 4.7 & 0 & 0 & 1 & 2.9 & 5 & 3.4 \\
\hline & Mainly not true & 0 & 0 & 0 & 0 & 5 & 143 & 5 & 3.4 \\
\hline & Mainly true & 0 & 0 & 0 & 0 & 0 & 0 & 0 & 0 \\
\hline & Completely true & 81 & 95.3 & 27 & 100.0 & 29 & 82.9 & 137 & 93.2 \\
\hline & Total & 85 & 100.0 & 27 & 100.0 & 35 & 100 & 147 & 100.0 \\
\hline \multirow{5}{*}{$\begin{array}{l}\text { I take care } \\
\text { about personal } \\
\text { hygiene }\end{array}$} & Completely false & 1 & 1.2 & 0 & 0 & 1 & 2.9 & 2 & 1.4 \\
\hline & Mainly not true & 0 & 0 & 0 & 0 & 2 & 5.7 & 2 & 1.5 \\
\hline & Mainly true & 0 & 0 & 0 & 0 & 0 & 0 & 0 & 0 \\
\hline & Completely true & 85 & 98.8 & 27 & 100.0 & 32 & 91.4 & 144 & 97.3 \\
\hline & Total & 86 & 100.0 & 27 & 100.0 & 35 & 100.0 & 148 & 100.0 \\
\hline \multirow[t]{5}{*}{ I eat healthily } & Completely false & 7 & 8.1 & 1 & 3.7 & 3 & 8.6 & 11 & 7.4 \\
\hline & Mainly not true & & 0 & 1 & 3.7 & 14 & 40.0 & 15 & 10.1 \\
\hline & Mainly true & 42 & 48.8 & 19 & 70.4 & 9 & 25.7 & 70 & 47.3 \\
\hline & Completely true & 37 & 43.0 & 6 & 22.2 & 9 & 25.7 & 52 & 35.2 \\
\hline & Total & 86 & 100.0 & 27 & 100.0 & 35 & 100 & 148 & 100.0 \\
\hline \multirow[t]{5}{*}{ I do sports } & Completely false & 11 & 13.1 & 5 & 18.5 & 5 & 14.7 & 21 & 14.5 \\
\hline & Mainly not true & 15 & 17.9 & 5 & 18.5 & 4 & 11.8 & 24 & 16.3 \\
\hline & Mainly true & 33 & 39.3 & 6 & 22.2 & 13 & 38.2 & 52 & 35.9 \\
\hline & Completely true & 25 & 29.8 & 11 & 40.7 & 12 & 35.3 & 48 & 33.1 \\
\hline & Total & 84 & 100.0 & 27 & 100.0 & 34 & 100 & 145 & 100.0 \\
\hline & Completely false & 4 & 6.8 & & 0 & 3 & 10 & 7 & 6.8 \\
\hline \multirow{4}{*}{$\begin{array}{l}\text { protection } \\
\text { during sexual } \\
\text { intercourse }\end{array}$} & Mainly not true & 5 & 8.5 & 2 & 14.3 & 4 & 13.3 & 11 & 10.7 \\
\hline & Mainly true & 11 & 18.6 & 3 & 21.4 & 2 & 6.7 & 16 & 15.5 \\
\hline & Completely true & 39 & 66.1 & 9 & 64.3 & 21 & 70 & 69 & 67.0 \\
\hline & Total & 59 & 100.0 & 14 & 100.0 & 30 & 100.0 & 103 & 100.0 \\
\hline \multirow[t]{5}{*}{ I have a hobby } & Completely false & 11 & 14.5 & 1 & 4.0 & 1 & 3.2 & 13 & 9.8 \\
\hline & Mainly not true & 9 & 11.8 & 2 & 8.0 & 4 & 12.9 & 15 & 11. 4 \\
\hline & Mainly true & 20 & 26.3 & 10 & 40.0 & 7 & 22.6 & 37 & 28.0 \\
\hline & Completely true & 36 & 47.4 & 12 & 48.0 & 19 & 61.3 & 67 & 50.8 \\
\hline & Total & 76 & 100.0 & 25 & 100.0 & 31 & 100.0 & 132 & 100.0 \\
\hline
\end{tabular}


International Journal of Child, Youth and Family Studies (2018) 9(1): 83-107

\begin{tabular}{|c|c|c|c|c|c|c|c|c|c|}
\hline \multirow{2}{*}{ Skill } & \multirow{2}{*}{ Answers } & \multicolumn{2}{|c|}{ Foster care } & \multicolumn{2}{|c|}{ Kinship care } & \multicolumn{2}{|c|}{ Residential care } & \multicolumn{2}{|c|}{ Total } \\
\hline & & $n$ & $\%$ & $n$ & $\%$ & $n$ & $\%$ & $n$ & $\%$ \\
\hline \multirow[t]{5}{*}{ I have friends } & Completely false & 4 & 4.8 & 1 & 3.7 & 2 & 5.9 & 7 & 4.8 \\
\hline & Mainly not true & 1 & 1.2 & & 0 & 0 & 0 & 1 & 0.7 \\
\hline & Mainly true & 19 & 22.6 & 4 & 14.8 & 11 & 32.4 & 34 & 23.4 \\
\hline & Completely true & 60 & 71.4 & 22 & 81.5 & 21 & 61.8 & 103 & 71.0 \\
\hline & Total & 84 & 100.0 & 27 & 100.0 & 34 & 100.0 & 145 & 100.0 \\
\hline \multirow{5}{*}{$\begin{array}{l}\text { I easily make } \\
\text { friendships }\end{array}$} & Completely false & 5 & 6.0 & 2 & 7.4 & 4 & 11.4 & 11 & 7.5 \\
\hline & Mainly not true & 6 & 7.1 & 0 & 0 & 2 & 5.7 & 8 & 5.5 \\
\hline & Mainly true & 30 & 35.7 & 11 & 40.7 & 11 & 31.4 & 52 & 35.6 \\
\hline & Completely true & 43 & 51.2 & 14 & 51.8 & 18 & 51.4 & 75 & 51.4 \\
\hline & Total & 84 & 100.0 & 27 & 100.0 & 35 & 100.0 & 146 & 100.0 \\
\hline \multirow{5}{*}{$\begin{array}{l}\text { I easily make } \\
\text { partnerships } \\
\text { (dating) }\end{array}$} & Completely false & 7 & 9.1 & 2 & 8.3 & 6 & 17.6 & 15 & 11.1 \\
\hline & Mainly not true & 10 & 13.0 & 5 & 20.8 & 8 & 23.5 & 23 & 17.0 \\
\hline & Mainly true & 32 & 41.6 & 8 & 33.3 & 11 & 32.4 & 51 & 37.8 \\
\hline & Completely true & 28 & 36.4 & 9 & 37.5 & 9 & 26.5 & 46 & 34.1 \\
\hline & Total & 77 & 100.0 & 24 & 100.0 & 34 & 100 & 135 & 100.0 \\
\hline \multirow{5}{*}{$\begin{array}{l}\text { I know where } \\
\text { and how to } \\
\text { look for } \\
\text { information } \\
\text { when needed }\end{array}$} & Completely false & 5 & 6.0 & 0 & 0 & 1 & 2.9 & 6 & 4.14 \\
\hline & Mainly not true & 2 & 2.4 & 0 & 0 & 4 & 11.8 & 6 & 4.14 \\
\hline & Mainly true & 33 & 39.3 & 9 & 33.3 & 16 & 47.1 & 58 & 40.0 \\
\hline & Completely true & 44 & 52.4 & 18 & 66.7 & 13 & 38.2 & 75 & 51.7 \\
\hline & Total & 84 & 100.0 & 27 & 100.0 & 34 & 100 & 145 & 100.0 \\
\hline
\end{tabular}

\section{Orientation Toward Emancipation}

Most of the young people in the sample knew of their right to remain in care until the age of $18(84.1 \%, n=127)$.

Life planning for leaving care: Participants were asked when they planned to leave care. The most frequent answer was "to stay in care as long as possible" $(43.7 \%, n=66)$; the next was "do not know" $(25.2 \%, n=38)$. Significantly fewer answered that they would leave care as soon as they could $(9.2 \%, n=14)$, and only a few that they would leave next year $(4.6 \%$, $n=7)$. The question was left unanswered by $17.2 \%(n=26)$. There were no significant differences by the type of placement.

When asked to specify where and with whom they expected to live after leaving care, $35.8 \%(n=54)$ of youth responded, although some $(4.6 \%, n=2)$ stated only the place of residence. Others answered that they would live with relatives $(10.5 \%$ of the sample, $n=16)$, alone $(9.3 \%, n=14)$, with mother or siblings $(6.6 \%, n=10)$, with a foster family $(4.6 \%, n=7)$, in the current placement $(1.3 \%, n=2)$, with a partner $(1.3 \%, n=2)$, with a future family of their own $(1.3 \%, n=2)$, with a $\operatorname{dog}(2.9 \%, n=3)$, and with a friend $(1.3 \%, n=2)$.

Feelings related to leaving alternative care: When asked about their feelings on leaving alternative care (six choices, with the possibility of multiple selections), 144 young people responded. At least one of the negative feelings listed was selected $62.5 \%$ of the time $(n=90$; mean of negative feelings $=1.51)$. The most commonly chosen feeling was sadness $(34.0 \%$ of 
responses, $n=9$ ), followed by anxiety $(32.6 \%, n=47)$ and fear $(27.8 \%, n=40)$. Among the positive emotions, the most frequent response was excited $(23.6 \%, n=34)$, while a lower number indicated happiness $(16.0 \%, n=23)$. The least frequent response was indifference $(13.2 \%, n=19)$. There were no significant differences by the type of placement to any feeling, but marginal significance was evident with the feeling of fear (Pearson's chi-squared[2] $=4.671$, $p=.0 .97$ ), with higher results for those in residential care than those in family placements. The results are consistent with the findings of the focus groups in which all youth participants spoke of exposure to stress regarding the transition to independence.

Another question about feelings was "What upsets you in connection with leaving care?". With the possibility of multiple choices (including "Nothing upsets me") and an open response ("Other"), 141 respondents replied and most identified at least one thing that upset them $(63.8 \%$, $n=90)$. The average number of positive responses was $1.09(S D=1.114)$, with a range from 1 to 5. Many respondents were worried that they would not be able to care for themselves $(29.1 \%)$ and that they did not know what would happen to them on leaving care $(27.7 \%)$; others were upset that they didn't have a plan for where to live (24.1\%). Eight respondents (5.7\%) gave other answers, of which the most common was that they were upset about the anticipated difficulty of finding a job $(2.1 \%, n=3)$. Pearson's chi-squared test showed significant differences between types of alternative care on the answers "I do not have a plan where I will live" (Pearson's chisquared[2] $=8.089, p=.018)$, "I don't know what will happen to me when I leave care" (Pearson's chi-squared[2] = 7.238, $p=.027$ ) and "Nothing upsets me" (Pearson's chi-squared[2] $=7.597, p=.022$ ). In all cases, the biggest difference was between the responses of participants in residential care and those in kinship care (see Table 9).

Table 9 Self-Assessment of Anxiety about Leaving Care

\begin{tabular}{|c|c|c|c|c|c|c|c|c|}
\hline \multirow{3}{*}{$\begin{array}{l}\text { What upsets you in connection with } \\
\text { leaving care? }\end{array}$} & \multicolumn{8}{|c|}{ Type of care } \\
\hline & \multicolumn{2}{|c|}{$\begin{array}{c}\text { Foster care } \\
(n=81)\end{array}$} & \multicolumn{2}{|c|}{$\begin{array}{l}\text { Kinship care } \\
(n=26)\end{array}$} & \multicolumn{2}{|c|}{$\begin{array}{c}\text { Residential } \\
\text { care }(n=34)\end{array}$} & \multicolumn{2}{|c|}{$\begin{array}{c}\text { Total } \\
(n=141)\end{array}$} \\
\hline & $\mathrm{N}_{\mathrm{p}} *$ & $\%_{\mathrm{p}} * *$ & $\mathrm{~N}_{\mathrm{p}} *$ & $\%_{\mathrm{p}} * *$ & $\mathrm{~N}_{\mathrm{p}} *$ & $\%_{\mathrm{p}} * *$ & $\mathrm{~N}_{\mathrm{p}} *$ & $\%_{\mathrm{p}} * *$ \\
\hline $\begin{array}{l}\text { I don't know what will happen to me } \\
\text { when I leave care }\end{array}$ & 24 & 29.6 & 2 & 7.7 & 13 & 38.2 & 39 & 27.7 \\
\hline I do not have a plan where I will live & 17 & 21.0 & 3 & 11.5 & 14 & 41.2 & 34 & 24.1 \\
\hline I don't have enough support & 4 & 4.9 & 0 & 0.0 & 4 & 11.8 & 8 & 5.7 \\
\hline Will I manage to take care of myself & 20 & 24.7 & 8 & 30.8 & 13 & 38.2 & 41 & 29.1 \\
\hline $\begin{array}{l}\text { Will I manage to take care of others } \\
\text { that I should take care for }\end{array}$ & 13 & 16.0 & 4 & 15.4 & 8 & 23.5 & 25 & 17.7 \\
\hline Nothing upsets me & 32 & 39.5 & 13 & 50.0 & 6 & 11.8 & 51 & 36.2 \\
\hline Other & 4 & 4.9 & 1 & 3.8 & 3 & 8.8 & 8 & 5.7 \\
\hline
\end{tabular}

$* \mathrm{~N}_{\mathrm{p}}$ - number of positive responses; $* * \%_{\mathrm{p}}$ - percentage of positive responses

The results of focus group discussions: Participants in family care (kinship or foster) talked differently about preparations for independence than did those in residential care, who 
International Journal of Child, Youth and Family Studies (2018) 9(1): 83-107

emphasised personal strengths: "You decide by yourself to get serious, no one will do it for you" (If7). They declared that they would need to rely on their own strengths because they could not count on the help of others in the future. The girls especially emphasised that they would need a job, because if they got married, they did "not want to depend on a husband". For example, one said "I know I can do it, so far I have managed and I will. I do not want to depend on my husband and to wait for him to give me the money to eat" (If4). When we asked young people from family care if there was anything helping them to prepare for independence, apart from the support of foster parents or relatives, one answered, "Certainly there is, but we cannot remember [talking about it]" (If1). When it came to support after leaving care, participants in family care either said that they would stay with relatives or get information from foster care counsellors. They had not discussed about it with anyone and even though they knew they were entitled to some forms of support, they were not sure what was included.

\section{Perception of the Future}

Perception of the future was assessed by answers given to ten items, with the respondent estimating the chances that particular events would happen to them in the next 5 years. Each item was answered on a five-point Likert scale, ranging from 1 (least likely) to 5 (extremely likely). The number of youth that answered the questions varied from 139 to 149 (Table 10). Most estimated high probabilities for desirable outcomes: to have good relationships with people $(92.7 \%)$, to become successful in business $(84.6 \%)$, and to have a good marriage and family (71.1\%). On the other hand, very few young people expected to become a victim of violence $(2.8 \%)$, to suffer serious health issues due to bad habits $(4.8 \%)$, and to use social assistance $(6.4 \%)$. About half felt that they were likely to make a contribution to society $(53.9 \%)$ and to have a lot of money $(49.0 \%)$.

Table 10 Perception of the Future of Care Leavers

\begin{tabular}{lrrrrc}
\hline \multicolumn{1}{c}{ What do you expect in next five years? } & $n$ & \multicolumn{1}{c}{$n_{4,5} *$} & $\%_{4,5} *$ & \multicolumn{1}{c}{$M$} & \multicolumn{1}{c}{$S D$} \\
\hline To have success in work & 149 & 126 & 84.6 & 4.31 & 0.874 \\
To have good marriage and family & 149 & 106 & 71.1 & 4.00 & 1.311 \\
$\begin{array}{l}\text { To have serious health issues due to } \\
\text { bad habits (smoking alcohol, drugs...) }\end{array}$ & 146 & 7 & 4.8 & 1.40 & 0.962 \\
To have a lot of money & 146 & 72 & 49.0 & 3.52 & 1.131 \\
To make contribution to the society & 139 & 75 & 53.9 & 3.39 & 1.977 \\
To become victim of violence & 144 & 4 & 2.8 & 1.18 & 0.670 \\
To use social assistance & 140 & 9 & 6.4 & 1.46 & 1.005 \\
To get arrested & 144 & 7 & 4.9 & 1.21 & 0.824 \\
To have good relationships with people & 145 & 134 & 92.7 & 4.69 & 0.755 \\
To be the leader in community & 139 & 56 & 40.3 & 3.17 & 1.304 \\
\hline
\end{tabular}

$* n_{4,5}$ and $\%_{4,5}$ are the number of and percentage of respondents answering 4 or 5 on the Likert scale 
International Journal of Child, Youth and Family Studies (2018) 9(1): 83-107

There were significant differences by type of placement on six out of ten items (Table 11). The number of respondents who answered the questions ranged from 80 to 85 in foster care, 25 to 27 in kinship care, and 32 to 35 in residential care.

Our participants in foster care had the most positive expectations for the future. They assessed their chance of being successful in business significantly higher than did those in kinship $(t[110]=2.639, p=.010)$ and residential care $(t[118]=2.162, p=.033)$. They also estimated their chance of having a lot of money in the future as significantly higher than did those in kinship $(t[108]=2.702, p=.008)$ and residential care $(t[118]=2.201, p=.030)$, and their chance to have a good marriage and family as significantly higher than did those in residential care $(t[47.9]=2.501, p=.016)$.

Our participants in residential care had the most negative expectations of the future. They reported a significantly greater expectation of needing social assistance $(t[38.3]=2.188, p=$ $.035)$ and of being arrested $(t[37.6]=2.066, p=.046)$ than did those in foster care. Those in residential care assessed their chances of experiencing serious health issues due to bad habits (smoking, alcohol, drugs, etc.) as significantly higher than did those in kinship care $(t[45.1]=$ 2.862, $p=.006)$.

Table 11 Significant Differences in Perception of Future by Type of Care

\begin{tabular}{|c|c|c|c|c|c|c|c|c|c|}
\hline \multirow{3}{*}{ Expectations } & \multicolumn{6}{|c|}{ Type of care } & \multirow{2}{*}{\multicolumn{3}{|c|}{ Significant differences }} \\
\hline & \multicolumn{2}{|c|}{ Foster care } & \multicolumn{2}{|c|}{ Kinship care } & \multicolumn{2}{|c|}{ Residential care } & & & \\
\hline & $M$ & $S D$ & $M$ & $S D$ & $M$ & $S D$ & $F$ & $d f$ & Sig. \\
\hline Success in work & 4.48 & .717 & 4.04 & .898 & 4.11 & 1.105 & 4.002 & $\begin{array}{r}2 \\
144\end{array}$ & .020 \\
\hline $\begin{array}{l}\text { Good marriage and } \\
\text { family }\end{array}$ & 4.24 & 1.095 & 3.81 & 1.415 & 3.51 & 1.579 & 4.363 & $\begin{array}{r}2 \\
144\end{array}$ & .014 \\
\hline Health difficulties & 1.34 & .941 & 1.12 & .431 & 1.74 & 1.197 & 3.664 & $\begin{array}{r}2 \\
141\end{array}$ & .028 \\
\hline Lots of money & 3.75 & 1.034 & 3.12 & 1.013 & 3.26 & 1.314 & 4.522 & $\begin{array}{r}2 \\
142\end{array}$ & .012 \\
\hline $\begin{array}{l}\text { Contribution to } \\
\text { society }\end{array}$ & 3.71 & 1.076 & 3.46 & 1.240 & 3.82 & 3.557 & .244 & $\begin{array}{r}2 \\
135\end{array}$ & .784 \\
\hline Victim of violence & 1.18 & .722 & 1.08 & .272 & 1.26 & .751 & .576 & $\begin{array}{r}2 \\
139\end{array}$ & .564 \\
\hline Social assistance & 1.30 & .753 & 1.42 & .987 & 1.88 & 1.408 & 3.923 & $\begin{array}{r}2 \\
135\end{array}$ & .022 \\
\hline Arrest & 1.09 & .477 & 1.12 & .60 & 1.57 & 1.357 & 4.691 & $\begin{array}{r}2 \\
139\end{array}$ & .011 \\
\hline $\begin{array}{l}\text { Good relations with } \\
\text { people }\end{array}$ & 4.74 & .661 & 4.69 & .61769 & 4.55 & 1.034 & .771 & $\begin{array}{r}2 \\
140\end{array}$ & .464 \\
\hline $\begin{array}{l}\text { Leader in } \\
\text { community }\end{array}$ & 3.26 & 1.319 & 3.08 & 1.288 & 3.00 & 1.295 & .529 & $\begin{array}{r}2 \\
134 \\
\end{array}$ & .590 \\
\hline
\end{tabular}


International Journal of Child, Youth and Family Studies (2018) 9(1): 83-107

\section{Discussion}

In our analysis of preparedness for emancipation of young people leaving alternative care, the following indicators were chosen: stability of placement in care, state of general and mental health, success and aspirations in schooling, social support, life skills (e.g., self-care and housekeeping) and social skills, orientation toward emancipation, and perception of the future. These indicators of preparedness were most common in the international literature on young people leaving alternative care; however, as no comparable research has been conducted in Serbia, it is possible that preparedness indicators could be different for Serbian youth.

Most of the participants in our study had been in one or two placements, which suggests that they had stability of placement. However, those placed in residential care had more changes of placement than those in family care, suggesting that those in residential care face more risks in completing a successful emancipation. Significant differences have been found among youth in different types of care on various indicators of preparedness. Youth in kinship care mostly show higher scores and better outcomes than youth in residential care. One of the reasons could be that stability of placement is higher among youth in family placements; another reason could be differences in how care leavers are treated, as the social system doesn't give any support to those who have left residential care.

Health is a good predictor of resilience among youth (Courtney \& Dworsky, 2006). Youth from the sample assessed their physical and mental health generally as good and the vast majority reported that they didn't need any support concerning their health habits and didn't believe that they were likely to experience health problems in the future.

However, the data further suggest that youth leaving care are in fact at risk for future health issues. Almost two thirds of our participants responded in the questionnaire that thinking about leaving care caused them negative feelings (sadness, fear, anxiety) and that they were upset about the changes that awaited them, which suggests that these youth were under stress that was becoming more intense as the leaving care time approached. All of the young people in the focus groups talked about exposure to stress due to their approaching independence. Studies have shown that chronic exposure to stress leads to a drop in physical health and increases susceptibility to disease (Bick, Calvo, \& Mootha, 2012). The worse the condition of their general and mental health, the less youth leaving care will be able to cope with stress, as shown in previous studies (Williams, Lindsey, Kurtz, \& Jarvis, 2001). In some cases, their mental health might be impaired because of negative feelings related to leaving care. The findings of this research show that youth in residential care assessed their overall health and health care as worse than did the other two groups; one may wonder what outcomes can be expected for these youth. The data suggest that it would be useful to conduct research on linkages between resilience in youth and their assessment of general and mental health. 
International Journal of Child, Youth and Family Studies (2018) 9(1): 83-107

It is a positive finding that young people have aspirations, but the fact that one quarter are unsatisfied with their school success suggests that the educational system should be adjusted to support youth by recognizing that they are facing difficulties transitioning into adulthood. Youth leaving care need an individualized educational approach in order to reach their potential and achieve greater personal satisfaction.

Our results show that the participants felt that they were receiving at least some support. The most significant support available to them in all three types of placement came from siblings, friends, and case managers. However, some participants didn't know that they had a case manager, which corroborates previous research on alternative care in Serbia in which some young people reported in interviews that they did not know who their case manager was (Burgund \& Žegarac, 2014). The relatively high percentage of missing teachers reported might be the result of the custom in some parts of Serbia of calling teachers in high school "professors". Almost all respondents believe that they can rely on adults and on friends, and many of them report that they can count on foster parents or caregivers. Young people in family placements had substantial help from the foster care system, while those in residential care had less support from residential staff. Young people in kinship care seem to have the most social support, primarily because of the support they receive from extended family (relatives), but also because they receive more help from teachers. The finding that they need less support in finance and housing might indicate that they receive more substantial support from their relatives. The support from the social system is most visible in qualitative assistance from the foster care system, less from residential care staff and case managers, and least from teachers.

The young people in residential care were in the least favorable position: they had less support from extended family, friends, teachers, and professionals in the social system, which left them to rely mostly on their own strengths. It is not surprising that they were the group that most frequently didn't know what would happen to them after leaving care and that they had mostly negative expectations of the future.

Analysis shows that young people felt they had the least support in finding a job, housing, and finance, and that these were the areas in which they most needed support. The findings suggest that young people expect that the system will provide them with help and accommodation, and provide an emergency response in crisis. Emotional support is not expected from workers in the alternative care system.

It seems that the preparation for independence of young people in foster and kinship care is postponed.With youth in family placement, we can assume that attachment and dependence have been nurtured, because for most of those youth the goal is to remain with the foster or kinship family, even though that is contrary to the rules of family care. It is certainly not what other stakeholders who are actively participating in the planning for emancipation expect (Žegarac, 2014b). 
Interestingly, both the focus groups and surveys suggest that the biggest concern with the independence of young people leaving alternative care is financial stability. At the same time, one third of survey participants clearly expressed that they need help in the form of advice. This suggests the young people have not yet developed the stability and self-reliance needed for independence. No matter how organised their move into independence is, it seems that young people need to have a person they can rely on, and from whom they can get help. Many countries have developed a system with professionals who have the responsibility, experience, knowledge, and competencies to help and empower young people without parental care to become independent (Žegarac, 2014b).

The young people from the sample largely perceive their future in positive terms. Most expected to have good relations with people, success in business, and a good marriage, and didn't expect to have problems with the law, violence, poverty, or health. The perception of the future is slightly more negative when it comes to making a lot of money and higher aims such as making a contribution to society and becoming a community leader.

The emotional responses of our participants to their future prospects included two dominant positive feelings, excitement and happiness; on the negative side, and more frequently, feelings of sadness, anxiety, and fear were reported. The fact that almost two thirds of young people felt upset about leaving alternative care suggests that they were not adequately prepared for transition. On the other hand, the fact that most young people appear to have positive expectations for the future can give us hope. If we encourage the resilience of young people and enable them to see themselves more as successful than unsuccessful, with adequate support during the preparation and transition, they will be more likely to achieve autonomy, independence, and success in adulthood. From the time that young people enter the system of alternative care, they need supports that will enable them to build capacities, acquire skills, and learn how to find support.

\section{Limitations}

The concept of preparedness for emancipation is a challenge to conceptualise and therefore measure because it depends on subjective assessment. Our effort to overcome this problem was focused on establishing some objective indicators. The special challenge in this research is the difficulty of assessing the readiness for emancipation of youth who are still in alternative care, because it is hard to know if we're ready for things that we have not yet experienced. Assessment of their readiness and preparedness would be more reliable after independence, when the outcomes could be objectively measured.

This study is among the first of its kind in Serbia. Greater accuracy could be expected by validation of the questionnaire on preparedness (QLACFY) and identifying indicators that apply to young people in Serbia. 
International Journal of Child, Youth and Family Studies (2018) 9(1): 83-107

The study design was transversal. Emancipation is a process that has an individual duration for each person. Studies dealing with the measurement of outcomes at certain moments do not provide information about the process, but the process is indirectly inferred from the outcomes. Greater precision on the outcomes of preparedness could be derived from longitudinal studies on the same population of young people after a certain period of living independently. Longitudinal studies require resources and must overcome the challenge of contacting young people after independence, because their records may be lost, and youth, as studies have shown (e.g., Courtney \& Dworsky, 2006), often change their place of residence, work, and even contacts.

The sample of the focus groups was much smaller than intended due to participation being voluntary; most of the larger sample did not respond to the invitation to participate in focus groups. As a result, the subsample of the focus groups did not satisfy the requirements of saturation.

All these limitations are a result of the fact that the findings of existing studies are pioneering both in perceiving the situation of young people who are preparing to leave alternative care and in the methodological approach in this field.

\section{Conclusion}

This study suggests that there is a lack of a systematic approach to the planning process of emancipation of young people in alternative care, and that there is a need for research that would deal with the consequences of this systemic non-response.

This research explores the characteristics of young people in alternative care and their differences by type of care. Research has shown that the system support is not individualized enough to adequately prepare young people in all types of placements for the transition to independence. While young people in family care in most cases had system supports in place, they hesitated to leave their foster or kinship family. On the othe hand, youth in residential care had significantly less social support, which motivated them to try harder to attain success, but also caused stresses that impaired their capacity to cope with difficult situations. We have received encouraging results in the areas of school success, aspirations, and perceptions of the future in young people who have grown up in alternative care.

Previously conducted research (Burgund \& Žegarac, 2014) points to factors that affect independence: a feeling of security, the continuity and stability of the placement after leaving care, and the level of social support after leaving care. This research has shown that, for many young people in care, the support and experience of security and preparedness are missing. This may serve to stimulate an examination of the independence of young people leaving alternative care from the perspective of their relationships, identities, and life stories, not only from the narrow perspective of acquiring skills. 
International Journal of Child, Youth and Family Studies (2018) 9(1): 83-107

Recommendations for ways to improve the system in order to produce better outcomes for young people include:

- early intervention and family support in order to preserve and strengthen the ties and relations between young people and their parents and relatives;

- providing alternative care of good quality in order to compensate for negative experiences and the trauma of entering care for children and young people;

- working with young people on their life stories in order to help them form stable identities;

- $\quad$ supporting young people to build their support networks and feel that they are in a safe environment;

- changing the paradigms of systematic analysis of young people in alternative care that sees them as purely vulnerable, in order to encourage and enable their specific potentials and strengths;

- providing a gradual transition from care to independence;

- providing continuous support for young people having mental health problems and those who are faced with multiple problems;

- involving youth in decision-making processes relevant to their lives and the future; and,

- providing individualized plans for youth leaving residential care that would include a gradual transition to adulthood.

More research is needed to deal with outcomes, especially research with experimental and quasi-experimental designs. Longitudinal studies could provide a clearer understanding of the risks and protective factors on emancipation outcomes. As well, comparative studies conducted through international networks have not been sufficiently explored (Munro, Stein, \& Ward, 2005; Pinkerton, 2006). There is a need to develop stronger links between theoretical work, empirical evidence, and immediate practice. The lack of empirical studies in the field of alternative care has led to interpretations that are not sufficient for the construction of theoretical knowledge. 
International Journal of Child, Youth and Family Studies (2018) 9(1): 83-107

\section{References}

Bick, A. G., Calvo, S. E., \& Mootha, V. K. (2012). Evolutionary diversity of the mitochondrial calcium uniporter, Science, 336, 886. doi:10.1126/science.1214977

Burgund, A., \& Žegarac, N. (2014). “Jel' radiš ti u ponedeljak, pa ko će da baci kofu vode iza mene“: Iskustva i gledišta mladih na smeštaju, njihovih staratelja i voditelja slučaja ["Do you work on Monday, who will spill a bucket of water for me?" Views and experiences of youth on care, their caregivers and care managers]. In N. Žegarac (Ed.), U lavirintu socijalne zaštite - poruke istraživanja o deci na porodičnom i rezidencionalnom smeštaju [In the labyrinth of social protection: The lessons learned from children placed in family and residential care] (pp. 319-368). Belgrade, Serbia: Facuty of Political Sciences, University of Belgrade.

Courtney, M. E., \& Dworsky, A. (2006). Early outcomes for young adults transitioning from outof-home care in the USA. Child and Family Social Work, 11, 209-219. doi:10.1111/j.13652206.2006.00433.x

Creswell, J. (2003). Research design: qualitative, quantitative, and mixed method approaches. Thousand Oaks, CA: Sage.

Dixon, J., \& Stein, M. (2005). Leaving care: Throughcare and aftercare in Scotland. London, UK: Jessica Kingsley.

Đurić, S. (2005). Metodologija fokusgrupnog istraživanja [Methodology of focus group research]. Sociologija, 47(1), 1-26. Retrieved from http://www.doiserbia.nb.rs/img/doi/0038-0318/2005/0038-03180501001D.pdf

Maunders, D., Liddell, M. [Max], Liddell, M. [Margaret], \& Green, S. (1999). Young people leaving care and protection: A report to the National Youth Affairs Research Scheme. Hobart, Australia: Australian Clearinghouse for Youth Studies.

Montgomery, P., Donkoh, C., \& Underhill, K. (2006). Independent living programs for young people leaving the care system: The state of the evidence. Children and Youth Services Review, 28(12), 1435-1448. doi:10.1016/j.childyouth.2006.03.002

Munro, E. R., Stein, M., \& Ward, H. (2005). Comparing how different social, political and legal frameworks support or inhibit transitions from public care to independence in Europe, Israel, Canada and the United States. International Journal of Child and Family Welfare, 8, 191-202.

Pinkerton, J. (2006). Developing a global approach to the practice of young people leaving state care. Child and Family Social Work, 11(3), 191-198. doi:10.1111/j.1365-

$\underline{2206.2006 .00431 . x}$ 
International Journal of Child, Youth and Family Studies (2018) 9(1): 83-107

Refaeli, T. (2014, September). Longitudinal study among care leavers: Predictors of selfefficacy for higher education. Paper presented at the meeting of the European Scientific Association on Residential \& Family Care for Children and Adolescents, Copenhagen, Denmark.

RZSZ (2016). Deca u sistemu socijalne zaštite 2015 [Children in the social protection system 2015]. Belgrade, Serbia: Republički zavod za socijalnu zaštitu [Republic Institute for Social Welfare]. Retrieved from http://www.zavodsz.gov.rs/PDF/izvestaj2016/deca\%20u\%20sistemu\%20socijalne\%20zastit e\%202015.pdf

Stein, M. (2005). Resilience and young people leaving care: Overcoming the odds. London, UK: Joseph Rowntree Foundation.

Stein, M. (2006). Young people aging out of care: The poverty of theory. Children and Youth Services Review, 28(4), 422-434. doi:10.1016/j.childyouth.2005.05.005

Stein, M. (2009). Promoting resilience: Messages from research. In D. Hart (Ed.), Managing transitions from secure settings (pp. 44-48). London, UK: National Children's Bureau.

Tweddle, A. (2005). Youth leaving care: How do they fare? New Directions For Youth Development, 113(Spring), 15-31. doi:10.1002/yd.199

Williams, N. R., Lindsey, E. W., Kurtz, P. D., \& Jarvis, S. (2001). From trauma to resiliency: Lessons from former runaway and homeless youth. Journal of Youth Studies, 4, 233-253. doi:10.1080/13676260123589

Žegarac, N. (Ed.). (2014a). U lavirintu socijalne zaštite: pouke istraživanja o deci na porodičnom i rezidencijalnom smeštaju [In the labyrinth of social protection: The lessons learned from children placed in family and residential care]. Serbia, Belgrade: Faculty of Political Science, University of Belgrade.

Žegarac, N. (2014b). Pravo deteta na kvalitetno staranje - Analiza sprovođenja smernica Ujedinjenih nacija za alternativno staranje o deci u zemljama zapadnog Balkana [The child's right to quality care - Analysis of the implementation of the UN Guidelines for the Alternative Care of Children in the Western Balkans]. Sarajevo, Bosnia and Herzegovina: Save the Children International. 